\title{
Strengthening Indonesian Judges' Understanding of the Refusal and Annulment Grounds of Foreign Arbitral Awards
}

\author{
by Dodik Setiawan Nur Heriyanto*
}

\begin{abstract}
Business entities see arbitration as a forum where they can settle their disputes. This form of alternative dispute resolution provides a win-win situation for both parties involved in the debate. Arbitration is the only institution that has full authority to settle their disputes once parties entered into a consent to choose an arbitration committee over a classic judicial forum. Even though arbitral awards have a final and binding character, they may be challenged using two legal methods: refusal or annulment. Besides providing specific grounds of refusal, the New York Convention 1958 ruled that the annulment of a foreign arbitral award could be done by a "competent authority of the country in which, or under the law of which, the award was made”. Although Indonesia has ratified the Convention and has specific national regulations on arbitration, judges of the courts of the first and second instance in fact do not have sufficient understanding of the refusal and annulment grounds of foreign arbitral awards. The well-known case of Karaha Bodas Company v. Pertamina shows that judges of the District Court of Central Jakarta failed to exercise their jurisdiction to annul the Geneva arbitral award. The case is a very typical example of not thinking outside the box and disregarding international treaties that sadly seems to be a commonly followed 'habit' in many cases all over the world. This paper aims to criticize several mistakes in the judicial reasoning that lead to such outcomes in judicial practice. Moreover, this paper will explain ways to strengthen judges' ability to understand the international treaties ratified by their government, as their usual practice in the civil law system is to constantly rely on the hierarchy of national legislation.
\end{abstract}

Keywords: judges' reasoning, refusal, annulment, foreign arbitral award

\section{INTRODUCTION}

A number of arbitration institutions have been established for settling international commercial or business disputes. ${ }^{1}$ Parties to international contracts enjoy many advantages in pursuing arbitration to resolve their disputes, including privacy of the proceedings, maintenance of the business relationship if the parties so desire, and savings in terms of both cost and time (speedy process). ${ }^{2}$ Fortunately, parties may decide many aspects of the proceedings including the arbitrators, governing law, language, and the place of arbitration.

By choosing an arbitral forum, parties agree not to have their disputes resolved in national courts. ${ }^{3}$ However, enforcing arbitration awards under the New York Convention

1 Conflict Research Consortium, ‘Arbitration' <http://www.colorado.edu/conflict/peace/ treatment/arbitrat.htm> accessed 20 August 2007.

2 Slate (2004) 41, 44.

3 Drahozal (2000) 451, 452.

* PhD Student, Faculty of Law, University of Debrecen (Géza Marton Doctoral School of Legal Studies, University of Debrecen) and Lecturer, Faculty of Law, Islamic University of Indonesia. E-mail: dodiksetiawan@uii.ac.id 
$1958^{4}$ necessarily involves domestic courts. ${ }^{5}$ Even though this Convention obliges member nations to recognize arbitral awards as binding and enforce them unless a reason exists to refuse the request, the winning party is usually frustrated when faced with the national courts that still retain the power to sabotage the award enforcement despite respecting the Convention's provisions.

Optimism in relation to the enforcement of foreign arbitral awards through the Indonesian Arbitration Law faded out when the Central Jakarta District Court decided to annul the Geneva arbitral award in Perusahaan Pertambangan Minyakdan Gas Bumi Negara ("Pertamina"/Indonesia) v Karaha Bodas Company L.L.C ("KBC"/Cayman Islands) on August 27, 2002. This decision was criticized by the international experts regarding the competency of the District Court to annul foreign arbitral awards in light of the Indonesian Arbitration Act and the New York Convention 1958.

The case of Pertamina $v$ KBC is sadly an emblem of the continuing problems in enforcing arbitral agreements and awards. After an ICC Tribunal ordered Pertamina to pay \$261 million to KBC as compensation for cancelling an energy project in the wake of the Asian financial crisis, Pertamina refused to comply. ${ }^{6}$ Pertamina sought to annul the award in Switzerland, the arbitration's venue. ${ }^{7}$ The Swiss Court rejected Pertamina's application twice without ever reaching the merits. When KBC began to enforce the award by seizing assets in the United States, Hong Kong, Singapore, and Canada, Pertamina turned to its home court in Indonesia and petitioned the Central Jakarta District Court to annul the Swiss Arbitral Award under Indonesian law. In this case, the judges of this court asserted their jurisdiction and then annulled the award on unpredictable and unprincipled grounds. Indonesia's reputation in the global economy, not only as a participant in the arbitration regime, but also as a locale for foreign investment, will likely decline further in the Karaha Bodas vacatur. ${ }^{8}$ This became the starring case in the practice of international arbitration and triggered several cases which were unsupportive of the recognition of foreign arbitral awards.

Indonesia has made significant changes on its regulatory framework since the late 1980s with an effort to encourage economic growth, which was previously financed largely through both domestic and foreign private investments. ${ }^{9}$ How could the adoption of a reasonably modern international arbitration law have made so little difference to the Indonesian court? Answering this question is important because the success of international commercial arbitration as a system depends in large part on predictability at the enforcement stage. This study will rebuild judges' framework in enforcing foreign arbitral awards by analyzing the weakness of Indonesian law on arbitration and how this law should be properly regulated. Since any effort to amend the Indonesian Arbitration Act will face

4 United Nations Convention on the Recognition and Enforcement of Foreign Arbitral Awards, June 10, 1958, 330 U.N.T.S. 38. came into force on 7 June 1959, art.I (hereinafter New York Convention 1958)

5 Convention on the Settlement of Investment Disputes between States and Nationals of Other States, 27 August 1965, art.54 (hereinafter ICSID Convention).

6 Rubins (2005) 359, 363.

7 Rubins (2005) 359, 363.

8 U.S. Dept. of State, 'Background Note: Indonesia' <http://www.state.gov/r/pa/ei/bgn /2748. htm> accessed 25 November 2007.

9 U.S. Dept. of State, 'Background Note: Indonesia' <http://www.state.gov/r/pa/ei/bgn /2748. htm> accessed 25 November 2007. 
political challenges, this study will also provide alternative steps to improve the judges' ability to understand the annulment and refusal of foreign arbitral awards and encourage them to support foreign investment.

\section{PERTAMINA V KBC AS THE STARRING CASE}

The case of Pertamina $v$ KBC began when on November 28, 1994 Pertamina and KBC signed a Joint Operation Contract ("JOC”) that granted KBC geothermal development rights in West Java. ${ }^{10} \mathrm{KBC}$ and Pertamina also signed an energy sales contract ("ESC") with State-Owned Electricity Company ("PLN") ${ }^{11}$, in which PLN agreed to purchase from Pertamina the electrical energy produced at the Karaha Bodas geothermal facility. ${ }^{12}$ The aim of this contract was to provide the electricity necessary for PLN by using geothermal resources in Karaha Bodas, Garut, West Java. ${ }^{13}$

In the wake of the economic crisis of 1997-1998, due to the insistence of the IMF, the Indonesian government issued regulations suspending a number of infrastructure projects, including 27 private power contracts that had been entered into in the five or so preceding years. ${ }^{14}$ As a result of this policy, since the contracts set prices in dollars, payments in Rupiah (Indonesian currency) would have been up to six times higher than had been contemplated when the contracts were signed ${ }^{15}$, and so PLN could no longer afford to pay the contracted price. ${ }^{16}$

In September 1997, President Soeharto responded to the Asian financial crisis by issuing a decree suspending the KBC project. ${ }^{17}$ When KBC protested, Soeharto reversed his decision and reinstated the project in November $1997^{18}$ by a second decree. The difficult crisis situation on January 10, 1998 led to a third decree established to postpone the project. $^{19}$

After the third Presidential Decree ${ }^{20}$, KBC was notified by Pertamina and PLN on April 30, 1998 that the government's actions “constituted an event of force majeure” under

10 Rubins (2005) 374; 'Exclusive Right on Geothermal Resources Lifted’ (Jakarta Post Daily Newspaper 2000).

11 PLN is one of the dominant Indonesian national companies that works on the electricity supply for the nation.

12 Rubins (2005) 374.

13 Juwana (2002) 69.

14 Mills (2000) 192, 193, 194.

15 See <http://www.cr-law.co.uk/services/insurance/cases/case92.htm> accessed 30 August 2007.

16 See <http://www.cr-law.co.uk/services/insurance/cases/case92.htm> accessed 30 August 2007.

17 Rubins (2005) 375. Presidential Decree No.39 Year 1997 concerning Postponement of Government Project, State Owned Enterprises, and Private Sectors in Connection with Government/ State Owned Enterprise.

18 Presidential Decree No.47 Year 1997 concerning the Changing Status on Implementation of Government, State Owned Enterprise, and Private Sector's Project in Connection with Government/ State Owned Enterprise that Previously Suspended.

19 Embassy of the United States of America for Indonesia, 'Chronology of the Crisis' <http:// www.usembassyjakarta.org/econ/crisis.html> accessed 30 August 2007.

20 Presidential Decree No.5 Year 1998 concerning Annulment of Presidential Decree No. 47 Year 1997 concerning the Changing Status on Implementation of Government, State Owned Enterprise, and Private Sector's Project in Connection with Government/State Owned Enterprise that Previously Suspended. 
both contracts, ceased operations, and served the parties with notice of its intent to initiate arbitration. ${ }^{21}$ The legal considerations of the promulgation of this decree are the following: (a) to prevent monetary problems in Indonesia it is necessary to take steps in order to make the budget of each government body more efficient; (b) based on re-investigation of previous decisions it was found that continuing the government projects between both state owned enterprises and/or private enterprises in cooperation with the government, in fact will need a huge amount of funding in order to cope with the financial crisis.

Both of the contracts, JOC and ESC, dated November 28, 1994 contained an arbitration clause stating that if a dispute arises, parties agree to settle it in an arbitration tribunal, under the UNCITRAL Arbitration Rules. ${ }^{22}$

On September 30, 1999, after a full hearing in which all parties willingly participated, KBC obtained a Preliminary Award against Pertamina from an Arbitral Tribunal in Geneva, Switzerland. ${ }^{23}$ And on December 18, 2000, in the Final Award, the Tribunal held that Pertamina and PLN breached their contracts with KBC, because they had assumed the risk that government action would nullify the project. The final award was in KBC's favor. The panel awarded about \$261 million in damages, ${ }^{24}$ including \$111 million in costs and \$150 million in lost profits, plus $4 \%$ post-judgment interest. ${ }^{25}$ Then, Pertamina asked the Swiss Court to annul the award.

Using the final award, KBC commenced an action in the United States District Court for the Southern District of Texas, The U.S. District Court for the District of Delaware, The U.S. District Court for the Southern District of New York, The Court of the Queen's Bench in Alberta, the Hong Kong Court, and the High Court of Singapore to confirm the Final Award pursuant to the New York Convention. KBC selected these venues for confirmation because Pertamina at that time maintained a representative office and/or having its property in their jurisdiction.

On August 7, 2001 the Swiss Federal Tribunal finally and decisively dismissed Pertamina's appeal of the final award. Pertamina then had no further legal means to annul the final award. The Swiss Federal Tribunal, however, declined to hear Pertamina's appeal due to a procedural error in paying the appeal costs. ${ }^{26}$ Thus, the Swiss Federal Tribunal refused to annul the award and this Court ruled that it was enforceable. ${ }^{27}$

On March 14, 2002 Pertamina initiated a lawsuit against KBC in the District Court of Central Jakarta, seeking to prevent KBC from bringing or continuing enforcement proceedings anywhere in the world, and asked this court to annul the underlying arbitration award. ${ }^{28}$ On April 1, 2002 the District Court of Central Jakarta ordered KBC not to take any action to enforce the judgment and established a fine of 500,000 \$ per day against KBC for

21 Rubins (2005) 359, 363.

22 UNCITRAL Model Law on International Commercial Arbitration, 24 ILM 1302, adopted on 21 June 1985 (hereinafter UNCITRAL Model Law). Peradilan (2005) 6.

23 See 'Chronology' <http://www.karahabodas.com/legalchronology.php> accessed 25 November 2007.

24 See 'Chronology' <http://www.karahabodas.com/legalchronology.php> accessed 25 November 2007.

25 Peradilan (2005) 22.

26 Budidjaja (2002) 98.

27 Department Review of Court Decision International (2003) 90-91.

28 Embassy of the United States of America for Indonesia, 'Chronology of the Crisis' <http:// www.usembassyjakarta.org/econ/crisis.html> accessed 30 August 2007. 
violation of this injunction. The District Court of Central Jakarta found for the plaintiff, Pertamina, and annulled the valid award issued by the Swiss Arbitral Tribunal, primarily based upon breach of natural justice in the appointment of the arbitral tribunal and consolidation of the proceedings without party consent. The annulment was decided on August 27, 2002. It also found presumed fraud in the calculation of damages. ${ }^{29}$ The judges also punished KBC by ordering them to pay the trial costs to the amount of 539.000 IDR. ${ }^{30}$

Due to dissatisfaction with the decision of the District Court of Central Jakarta, and although its decision has no effect on KBC's right to payment or its enforcement efforts, KBC appealed to the Indonesian Supreme Court. Finally on November 3, 2004 the Indonesian Supreme Court issued a judgment declaring that the lower Jakarta court did not have authority to annul the International Arbitration Award and vacated the damages assessed against KBC. The Indonesian Supreme Court joined the courts of Hong Kong, Singapore, Canada and the US in upholding the Award. ${ }^{31}$

\section{A CENTRAL PROBLEM: RATIFICATION WITHOUT FULL ADOPTION}

The role of judges in the civil law system is primarily to make decisions based on legislative acts. Even though Indonesia ratified the New York Convention 1958 on October 7, 1981, in fact judges still do not base their decisions directly on the Convention. The main reason why judges do not rely on the New York Convention is due to the lack of literature on international treaties that have been ratified and translated into the Indonesian language. More importantly, Indonesia's ratification sometimes remains technically unclear. Most ratifications are not followed by the adoption of the provisions of international treaties into national legislation. The non-existence of treaty provisions in domestic regulations generates the uncertain judicial decisions that are far from the main purpose of the treaty. Judges also often claim that their own interpretation differs from the main substance of the treaty because the existing national legislation does not include such international obligations.

Indonesia ratified the New York Convention 1958 by a specific legal instrument called Presidential Decree ${ }^{32}$. This instrument only contains the government's assertion that it faithfully follows the New York Convention $1958 .{ }^{33}$ No such incorporation of substantial provisions contained in the New York Convention 1958 occurred in national legislation after 1981 and this led to uneasy and uncertain enforcement of foreign arbitral awards. Judges refused almost all enforcement requests. In one case, Nizar (Indonesia) v Navigation Maritime Bulgare (Bulgaria), the Supreme Court refused to implement the London arbitration award in favour of Navigation Maritime Bulgare because of the absence of

29 Mills (2000) 192, 193, 194.

30 Perusahaan Pertambangan Minyak Dan Bumi Negara v Karaha Bodas Co. (2002) Decision of Central Jakarta’ District Court No. 86/PDT.G/2002/PN.JKT.PST

31 Embassy of the United States of America for Indonesia, 'Chronology of the Crisis' <http:// www.usembassyjakarta.org/econ/crisis.html> accessed 30 August 2007.

32 Presidential Decree No. 34 Year 1981 concerning Ratification of New York Convention Year 1958 on the Recognition and Enforcement of Foreign Arbitral Awards (hereinafter Presidential Decree 1981).

33 There are only two provisions inside the Presidential Decree, consisting of the government assertion toward the Convention's ratification and the validity of the instrument's ratification. This substance is a common rule in all instrument ratification. 
national legislation related to the recognition and enforcement of international arbitration. ${ }^{34}$ Moreover, in the case of E.D. \& F Man Sugar Ltd. (UK) v YaniHaryanto (Indonesia), the Central Jakarta District Court judges did not respect the arbitration clause agreed upon by both parties by declaring that they were authorized to handle Yani Haryanto's petition and decided that the agreement is void because of public order contravention. ${ }^{35}$

In 1990, in an effort to improve its dramatically declining reputation in the business sector, the Supreme Court adopted the implementing regulation of Presidential Decree 1981. This regulation was adopted as the Supreme Court Regulation No. 1 Year 1990.36 This adoption had a positive effect, which was indicated by the exequatur granted by Supreme Court for some foreign arbitral awards as well as in the cases of United Molasses \& Co. (UK) v PT. Intra Waegolla of Jakarta (Indonesia) ${ }^{37}$, Ecom USA Inc. (Dallas, USA) v PT. MahameruCentratama Mills (Indonesia) ${ }^{38}$, and PT. Tripatria Citra Pratama (Indonesia) $\checkmark$ Abdulelah Jamal Al Zamzani cs. (Saudi Arabia) ${ }^{39}$.

After a deep examination of the substance, we can see that the Supreme Court Regulation 1990 provisions are merely related to the technical implementation of a foreign arbitral award and do not provide the conditions that must be met in order to recognize foreign arbitral awards in Indonesia. Again, this lack of incorporation of the New York Convention 1958's general content urged the judges to use their own interpretation in some specific cases. Although being aware that this implementing regulation had a positive impact on the implementation of foreign arbitral awards in Indonesia, the case of Sikinos Maritime Ltd. (Malta) $v$ PT. PerdataLaot (Indonesia) ${ }^{40}$ proved that the incomplete regulation leads to unpredictable judicial interpretation. The judges of the Supreme Court rejected the exequatur petition filed by Sikinos Maritime Ltd. as the winning party in the London Arbitral Award based their claim on the fact that the Memorandum of Agreement between the two sides had never been signed.41 These judges' interpretation drew sharp criticism from the applicant concerning that the agreement had obviously been signed and the judge proved to be less serious in delving deeply into the question whether those foreign awards either comply with the limits provided by the New York Convention 1958 or not.42 Moreover, in the case of E.D. \& F Man Sugar Ltd. (UK) v Yani Haryanto (Indonesia), by relying on the Supreme Court Regulation 1990, the Supreme Court upheld the decision of the District Court of Central Jakarta and refused to implement the London Arbitral Award ${ }^{43}$

34 Nizar v Navigation Maritime Bulgare (1983) Supreme Court Decision No. 2944K/PDT/1983

35 E.D. \& F Man Sugar Ltd. v Yani Haryanto (1988) Decision of Central Jakarta's District Court No. 499/Pdt/G/VI/1988/PN.JKT.PST

36 Supreme Court Regulation No. 1 Year 1990 concerning the Enforcement of Foreign Arbitral Awards (hereinafter Supreme Court Regulation 1990)

37 United Molasses \& Co. v PT. Intra Waegolla of Jakarta (1992) Supreme Court Order No. 2 Pen.Ex’r/Arb.Int/Pdt/1992

38 Ecom USA Inc. v PT. Mahameru Centratama Mills (1992) Supreme Court Order No. 4 Pen. Ex’r/Arb.Int/Pdt/1992

39 PT. Tripatria Citra Pratama v Abdulelah Jamal Al Zamzani cs. (1993) Supreme Court Order No. 1 Pen.Ex’r/Arb.Int/Pdt/1993

40 Sikinos Maritime Ltd. v PT. Perdata Laot (1992) Supreme Court Order No. 3 Pen.Ex’r/Arb. Int/Pdt/1992

41 Sikinos Maritime Ltd. v PT. Perdata Laot (1992) Supreme Court Order No. 3 Pen.Ex’r/Arb. Int/Pdt/1992

42 Longdong (1998) 239.

43 E.D. \& F Man Sugar Ltd. v Yani Haryanto (1990) Supreme Court Decision No. 1205 K/ 
by broadening the limits of public order rather than analyzing the content of the court's decision.

Due to the fact that Supreme Court Regulations are not included in the constitutional hierarchy of legislative acts the enforcement of foreign arbitral awards in Indonesia is uncertain and leads to judicial ignorance. With this reality, in 1999, the Government issued and enacted the Act No. 30 of 1999 concerning Arbitration and Alternative Dispute Resolution. ${ }^{44}$ However, this law still does not incorporate important provisions of the New York Convention 1958. For instance, although this law allowed the recognition of arbitral awards, there were still erroneous judicial decisions in refusing and annulling foreign arbitral awards. The phenomenal case of Pertamina $v$ KBC indicated that judges had not based their decision on the New York Convention. In another case, the Bankers Trust Company and Bankers Trust International, Plc. (New York, USA) v PT. Jakarta International Hotels \& Development (Indonesia) also proved that judges mainly focused on their authority to review the foreign arbitral award ${ }^{45}$ rather than on the power to execute or reject the award granted by the New York Convention 1958. The District Court of Central Jakarta rejected the enforcement application on the basis that it would be against Indonesia's "public order" while another domestic civil court's adjudication was challenged by the other party. ${ }^{46}$

Obviously, the New York Convention 1958 as an international treaty that has been ratified has an unclear position in the hierarchy of legislative acts. A Presidential Decree is not ipso facto a part of the national law that has the same binding power as a National Act, Government Regulation, or even Presidential Regulation. ${ }^{47}$ Constitutionally, Presidential Decree 1981 was treated no more than as an official instrument to be submitted before the United Nation (UN) Secretary General. ${ }^{48}$

Since Indonesia has a civil law system, law enforcement officials, especially judges, never refer their decisions directly to an international treaty unless such a treaty is set forth in specific legislation. Without adoption, the New York Convention 1958 possesses no clear position in the hierarchy of legislative acts. Act No. 25 Year 2007 on Foreign Investment is one of the best examples of the incorporation of substantial elements from the ICSID Convention that was ratified under the Act No. 5 Year $1968 .{ }^{49}$

Pdt/1990. It is quite an interesting case because this decision canceled the previous excequatur that held under Supreme Court Order No. 1/Pen.Ex'r/Arb.Int/Pdt/1991 on the basis that the District Court Decision No. 499/Pdt/G/VI/1988/PN.JKT.PST and High Court Decision No. 486/Pdt/1989/PT.DKI stated that the contract between the parties is null and void. Thus, the Supreme Court decided that by upholding the previous excequatur they would contradict public policy.

44 Act No. 30 Year 1999 concerning Arbitration and Alternative Dispute Resolution (hereinafter Indonesian Arbitration Act)

45 TheBankers Trust Company and Bankers Trust International, Plc. v PT. Jakarta International Hotels \& Development (1999) Decision of South Jakarta’s District Court No. 46/Pdt.G/1999/PN.JKT. SEL

46 Hwang (2008) 891, Soemartomo (2006) 73.

47 Under Indonesian constitutional hierarchy, the national laws divided based on their level of legal power from the highest level to the lowest level, such as: 1945 Constitution, Decree of People Consultative Assembly, Act, Government Regulation, Presidential Regulation, Local Law of Provincial Region, and Local Law of Sub Region. Act No. 12 Year 2011 concerning Legal Drafting Law, art.7 (1)

48 New York Convention 1958 art. IX (2)

49 Act No. 5 Year 1968 concerning the Ratification of Convention on the Settlement of Investment Disputes between States and Nationals of other States 
Indonesia, in fact, applies a dualist principle ${ }^{50}$ where international agreement and national law are separate areas, thus it is necessary to incorporate substantial parts of the treaty into national law. Through such incorporation, judges are able to base their decisions on existing national laws located in the hierarchy of legislation. Even if the Indonesian Arbitration Act Year 1999 is considered as the endorsement and incorporation of the New York Convention Year 1958 then all important parts of this Convention should be included in this Act and (if possible) it should specify guidelines that will provide for legal certainty for future award enforcement. UNCITRAL Model Law ${ }^{51}$ could be compared in providing the pertinent arbitration norms though this law is a non-binding rule. ${ }^{52}$ Hence, to fix the enforcement problem of foreign arbitral awards, it is necessary for Indonesia to amend the Indonesian Arbitration Act Year 1999 that sets out important grounds for the refusal and annulment of foreign arbitral awards regulated by the New York Convention 1958 and the Model Law as a reference for the amendment of the Act.

The effective amendment of the Indonesian Arbitration Act should also limit the scope of existing general norms such as the limitation of 'public order' as a ground of refusal that led to the judges' narrow interpretation. The Indonesian Arbitration Act only 'adopted' the public order set out in Article 66 paragraph (c) as grounds for refusal without any specific limitation. Moreover, article 70-72 of this Act governing annulment of arbitration award does not describe clearly as to what extent judges have power to annul the foreign award. This unclear law of annulment led to wrong judicial interpretations, as in the case of Pertamina $v$ KBC. All efforts to amend the existing Indonesian Arbitration Act by harmonizing it with the New York Convention and its development would lead to the modernization of the arbitration law, making it culturally neutral, promoting legal protection and certainty, and adopting a 'pro-arbitration approach'.53

\section{THINKING OUTSIDE THE BOX}

Making changes to the Indonesian Arbitration Act arguably requires an uphill struggle and long debate. Moreover, the political constellation will inhibit the efforts of amendment. This paper highlighted two other major efforts of improving the quality of judicial decisions. One of these was increasing the judges' capacity. In this matter, a judge must be willing to think outside the box or needs the ability to apply the relevant international treaties in certain cases. At this point, the judge should be aware that once a treaty is ratified, a state is automatically legally bound by all the international obligations contained within its provisions. Furthermore, the judge also should learn from previous mistaken decisions, though the civil law system does not utilize precedents. Studying past decisions will lead to less problematic, and more just, decisions.

50 Agusman argued that Indonesia is still in an unclear position on the matter of treaty ratification, either it is directly implemented or it needs adoption to national legal system. Agusman (2010) 96.

51 UNCITRAL Model Law on International Commercial Arbitration, 24 ILM 1302, adopted on 21 June 1985 (hereinafter UNCITRAL Model Law). Peradilan (2005) 6.

52 The Model Law is not a binding treaty and is different from the Convention but it is the suggested legal drafting guideline for lawmakers to adopt as a part of domestic legislation. HunterMartin (1985) 399.

53 Rajagukguk (2000) 
Arbitral awards include awards made by arbitrators appointed by the parties, as well as by arbitral tribunals chosen by the parties. ${ }^{54}$ 'International' means that the relevant arbitration involves a foreign element. The 'foreign element' arises where the parties' residence and place of business, the subject-matter of their arbitration agreement or dispute take place in different countries. ${ }^{55} \mathrm{~A}$ foreign element is material or significant if it can result in the parties' submission to the courts of another country, or the application of the laws of another country. The foreign element can be used as a starting point in determining the compatible law to interpret in the main dispute between the parties. Where domestic law is insufficient in relation to the regulation of those foreign elements, the judge shall rely on the treaty ratified by the state. The ability of the judge in qualifying facts and finding the right law both nationally and internationally need(s) to be sharpened or even given specific guidelines. The Supreme Court as the institution authorized to improve the quality of judges’ reasoning has a duty to broaden the judges` insight and increase their capability to apply international treaties directly enforceable in Indonesia.

The other, and very important, effort to maintain justice in the enforcement of foreign arbitral awards in Indonesia is the confirmation of the Supreme Court's role as the final proof reader of legal misapplication in every decision brought to them from the lower courts (judex juris). Even though the Indonesian Arbitration Act empowers the District Court of Central Jakarta to enforce or refuse foreign arbitral awards ${ }^{56}$ but the Supreme Court has the authority to hear, review, and rule on all final decisions made by appellate courts (lower courts) ${ }^{57}$. The cases of Pertamina $v$ KBC and PT. Bungo Raya Nusantara (Indonesia) $v$ PT. Jambi Resources Limited (Indonesia) ${ }^{58}$ proved the Supreme Court's position as the guardian of awards ${ }^{59}$ even though their work is still not maximum satisfactory. The role of the Supreme Court in correcting erroneous lower court decisions should be confirmed and maximized because of their position as the guardian of arbitral awards. ${ }^{60}$ It is necessary for the quality of the Supreme Court judges' reasoning to be strengthened through expertise in international private law and the judges' ability to comprehend treaty provisions.

\section{CONCLUSION}

Once an arbitration institution renders an award, it has a final and binding character but the victorious party requires the domestic court to enforce such award. Foreign arbitral awards can also be annulled by the Court if the procedure and/or substance of the decision is considered unjust. To maintain the award enforcement, the New York Convention 1958 provides grounds to refuse and set aside the foreign arbitral award. Although Indonesia ratified the New York Convention 1958 in 1981, obviously Court decisions are still far from being favourable towards pro-arbitration enforcement. The main modality to protect Indonesia from the darkness of arbitration enforcement is the amendment plan of the

54 New York Convention 1958 art. 1.

55 New York Convention 1958 art.1. (3)

56 Indonesian Arbitration Act No. 30 Year 1999 art. 65

57 Act No. 48 Year 2009 concerning Judicial Power, art.20 (2) (a)

58 PT. Bungo Raya Nusantara v PT. Jambi Resources Limited (2010) Supreme Court Decision No. 64 K/PDT.SUS/2010.

59 Hikmah (2013) 261.

60 Hikmah (2013) 261. 
Indonesian Arbitration Act to accommodate substantial parts of the New York Convention 1958 and/or the Model Law.

We cannot deny that any efforts of amendment will be confronted by political challenges in Parliament. Thus, this paper suggests two other assured effective measures to ensure foreign arbitral award enforcement: firstly, strengthening judges' capacity building and encouraging their willingness to apply relevant international treaties and secondly, confirm and maximize the role of the Supreme Court as the guardian of awards. All of these steps will ameliorate Indonesia's reputation in the eyes of investors and indirectly boost the country's economy.

\section{LITERATURE}

Agusman, D., Hukum Perjanjian Internasional: Kajian Teori dan Praktik Indonesia (Refika Aditama 2010).

Budidjaja, T., Public Policy as Grounds for Refusal of Recognition and Enforcement of Foreign Arbitral Awards in Indonesia (PT. Tatanusa 2002).

Department Review of Court Decision International, 'Effect of Award Annulled by a Country Lacking Primary Jurisdiction’ (2003) 59 JUL Journal of Dispute Resolution 90-91.

Drahozal, C. R., ‘Enforcing Vacated International Arbitral Awards: An Economic Approach’ (2000) 11 American Review of International Arbitration 451-479.

Hikmah, M., 'The Roles of the Supreme Court of the Republic of Indonesia in Enforcement of International Arbitral Awards in Indonesia’ (2013) 3 Indonesia Law Review 238-266.

Hunter, H. and Martin, J., 'The UNCITRAL Model Law' (1985) 13 International Business Lawyer 399-402.

Hwang, M., et.al, 'Survey of South East Asian Nations on the Application of the New York Convention' (2008) 25 Journal of International Arbitration 873-892.

Juwana, H., 'Pembatalan Putusan Arbitrase Internasional oleh Pengadilan Nasional' (2002) 21 Jurnal Hukum Bisnis 67-74.

Longdong, T. L. T., Asas Ketertiban Umum \& Konvensi New York 1958 (PT. Citra Aditya Bakti 1998).

Mills, K., 'Enforcement of Arbitral Awards in Indonesia' (2000) 6 International Arbitration Law Review 192-194.

Peradilan, V., 'Putusan Arbitrase Internasional Digugat Pembatalannya: Kasus Pertamina v. Karaha Bodas’ (2005) 20 Majalah Hukum Tahun 4-27.

Rajagukguk, E., 'Economic Law: Legal Reform in Indonesia' in RM Talib Puspokusumo (ed), Reformasi Hukum di Indonesia: Sebuah Keniscayaan (Tim Pakar Hukum Departemen Kehakiman dan HAM RI 2000).

Rubins, N., 'The Enforcement and Annulment of International Arbitral Awards in Indonesia' (2005) 20 American University International Law Review 359-401.

Slate, W. K., 'International Arbitration: Do Institutions Make a Difference?’ (2004) 31 Wake Forest Law Review 41-64.

Soemartomo, G. P., Arbitrase dan Mediasi di Indonesia (Gramedia Pustaka Utama 2006). 